\title{
ОСОБЕННОСТИ ФОРМИРОВАНИЯ СОЦИАЛЬНОЙ ИНФРАСТРУКТУРЫ
}

Анализ социальной инфраструктуры города Брянска позволил выявить ряд проблем, свойственных низкобюджетному строительству. Высокая плотность застройки приводит к проблемам нехватки объектов социальной инфраструктуры во вновь построенных жилых комплексах, перегружает транспортные магистрали города. Инвестиции в комплексную жилую застройку целесообразно сопровождать развитием учебных, спортивных, досуговых и иных объектов социальной инфраструктуры.

Ключевые слова: региональная экономика, развитие региона, социальная инфраструктура, жилищное строительство, рынок недвижимости.

I.V. Shlemina

\section{FEATURES OF SOCIAL INFRASTRUCTURE FORMATION}

The territory of Bryansk is provided with power, transport, engineering and social infrastructure, the level of infrastructure development, differs in different districts of the city. Formation and development of social infrastructure in the region involves creating and extension of facilities supporting the vital activities: schools, hospitals, sports complexes, and social infrastructure of comfort (for free choice of leisure - park zones, facilities for physical exercises, etc.), and also the objects of cultural heritage, historical monuments. At the same time, in the context of Russian and interna-

\section{Введение}

Территория города Брянска обеспечена энергетической, транспортной, инженерной и социальной инфраструктурой, уровень развития инфраструктуры, различается в разных районах города. В тоже время, в условиях российского и международного экономического кризиса в регионе возникли тенденции строительства низкобюджетного жилья в эконом-секторе, застройка осуществляется на окраинах города, складывается тенденция жилой застройки без объектов социальной инфраструктуры, расположенной в шаговой доступности от построенного жилого микрорайона. Возникают следующие проблемы комплексного развития новых территорий: снижение покупательного спроса населения; дефицит инвестиционных ресурсов, политика снижения издержек в строительстве жилой недвижимости у застройщиков; недостаточное инвестирование в развитие социальной инфраструктуры, что в tional economic crisis the construction tendencies of cheap housing in the economy sector are observed in the region, building is carried out on the suburbs of the city, there is a tendency of the residential building without objects of social infrastructure located within easy reach from the residential district that in total leads to a reduction in the quality of life in the region.

Keywords: regional economy, development of the region, social infrastructure, housing construction, real estate market, to decline in quality of life in the region.

совокупности приводит к снижению качества жизни в новых построенных комплексах в регионе.

Целью исследования является анализ особенностей и проблем строительства жилых объектов в условиях экономического кризиса и их влияние на качество жизни населения в регионе.

\section{Анализ тенденций развития социальной инфраструктуры}

В рамках социокультурной среды и сферы активности человека можно выделить определенные компоненты: культурно-историческое наследие или историческая среда обитания человека, мера ее освоения и востребованности; художественная среда обитания человека; социальнопсихологическая среда обитания (характер межличностных отношений, форм и способов совместной жизнедеятельности людей); духовно-нравственная среда обитания; экологическая среда обитания - со- 
стояние природного окружения, а также самоопределение человека в природном мире, отношение человека к природе.

Основными сферами жизнедеятельности человека являются: производственная, образовательная, досуговорекреационная, физкультурно-спортивная, оздоровительная, информационная.

Таким образом, социокультурная среда - это окружающие человека материальные, социальные, институциональные и духовные условия его формирования, развития и самореализации. Социокультурная среда жизнедеятельности как человека, так и социальной группы региона изменяется, развивается, преобразовывается. Оказывая решающее воздействие на развитие и формирование личности, среда в то же время изменяется, преобразуется под влиянием творческой активности человека, благодаря которой потенциалы среды становятся реальными возможностями развития личности, условиями ее самореализации.

Понятие социальной инфраструктуры в различных исследованиях рассматривается в узком смысле как минимальный жизненный стандарт и в широком смысле как комфортный, экологичный уровень жизни в условиях занятости.

В условиях ограниченности ресурсов из рассмотрения исключаются вопросы строительства социальной инфраструктуры «высокого» уровня для качественного культурного отдыха и развития спортивных способностей, которая позволяет создать высокий уровень качества жизни в городах или сельских поселениях, преодолеть ограниченность и скудность предоставляемых возможностей для качественного поведения времени, приводит к неравномерному развитию отдельных территорий региона, снижает туристическую привлекательность региона.

В последние годы для выравнивания качества жизни в различных районах города Брянска и Брянской области реализованы программы развития технической инфраструктуры, необходимой для комфортного проживания. Проведена газификация сельских районов и городских поселков с индивидуальной застройкой, осуществле- но строительство объектов общественного назначения (строительство дорог по области, расширение моста через р. Десна и другие проекты), объектов спортивной инфраструктуры и пр.

Создается инновационная инфраструктура для ведения бизнеса. Для содействия бизнесу действуют региональные программы поддержки предпринимателей, подготовлены площадки для реализации бизнес-проектов потенциальных инвесторов в бизнес-инкубаторе региона, проводятся регулярные мероприятия по развитию компетенций населения в сфере предпринимательства, IT-технологий, маркетинга и рыночных коммуникаций с приглашением лучших отраслевых экспертов и специалистов.

Особое внимание уделено развитию социальной инфраструктуры. В рамках государственных программ РФ реализуются проекты развития здравоохранения: профилактики заболеваний и повышения качества предоставляемых медицинских услуг.

Инфраструктура для досуга связана с сохранением культурных и исторических объектов региона, а также развитием туристического кластера.

В Брянске предлагаемые жилые помещения в жилых комплексах (ЖК) отличаются разным уровнем комфорта, доступа к городской инфраструктуре и инфраструктуре собственно жилого комплекса (табл.1).

Анализ предложения застройщиков города Брянска показал, что застройка малогабаритных квартир, в большинстве случаев ведется без объектов социальной инфраструктуры и дополнительных объектов самих жилых комплексов.

Как видно из табл.1, фирмызастройщики обустраивают территорию жилых комплексов в основном открытой автостоянкой и простейшей детской площадкой (1-2 песочницы, качели, турники). Наличие и близкое расположение таких важных объектов, как детские сады, школы, поликлиники и больницы обуславливается местоположением жилого комплекса. Все они - муниципальные, и заселение новых жилых комплексов приводит к значительному усилению нагрузки на эти объекты. 
Анализ предложения объектов инфраструктуры в жилых комплексах

\begin{tabular}{|l|l|}
\hline \multicolumn{1}{|c|}{ Название жилого комплекса } & \multicolumn{1}{|c|}{ Наличие объектов инфраструктуры } \\
\hline ЖК «Соловьи», & $\begin{array}{l}\text { Парковая зона (не относится к ЖК, просто } \\
\text { рядом расположен парк) } \\
\text { Закрытая территория, } \\
\text { Детская площадка, } \\
\text { Открытый и крытый паркинг } \\
\text { Гостевой паркинг: Автостоянка } \\
\text { Близкое расположение магазинов, меди- } \\
\text { цинских учреждений, банков, кафе. }\end{array}$ \\
\hline ЖК по улице Почтовой & $\begin{array}{l}\text { Детская площадка } \\
\text { Паркинг: Автостоянка }\end{array}$ \\
\hline ЖК «Мичуринский» & $\begin{array}{l}\text { Паркинг: Автостоянка } \\
\text { ЖК «На Флотской» }\end{array}$ \\
\hline ЖК «Белобережская» & $\begin{array}{l}\text { Детская площадка } \\
\text { Паркинг: Автостоянка }\end{array}$ \\
\hline Сэропорт» & $\begin{array}{l}\text { Современная детская площадка, } \\
\text { Паркинг: Автостоянка, } \\
\text { Уличные спортивные тренажеры, } \\
\text { Близкое расположение детского сада, шко- } \\
\text { лы, магазинов, медицинских учреждений, } \\
\text { банков, кафе. }\end{array}$ \\
\hline $\begin{array}{l}\text { Детская площадка } \\
\text { Паркинг: Автостоянка } \\
\text { Близкое расположение детского сада, шко- } \\
\text { лы, магазинов, медицинских учреждений, } \\
\text { банков, кафе. }\end{array}$ \\
\hline
\end{tabular}

Снижение доходов федерального и регионального бюджетов не позволяет планировать масштабное строительство новых объектов социальной инфраструктуры в новых микрорайонах.

Таким образом, анализ факторов изменяющих структуру предлагаемого жилья на рынке жилой недвижимости показывает, что наблюдается тенденция строительства малобюджетного жилья, что проявляется в следующем:

- снижение общей площади квартиры по сравнению с докризисными показателями,

- строительство жилых комплексов за городом и на земельных участках с невысокой стоимостью,
- применение технологий строительства из недорогих строительных материалов, с помощью нетрадиционных экономичных технологий.

Строительство малобюджетного жилья создает проблемы социальноэкономического характера: территориальное планирование в условиях нехватки объектов социальной инфраструктуры в построенных жилых комплексах, транспортная нагрузка на магистрали для въезда/выезда в направлении районов с развитой инфраструктурой (рабочих мест, центров досуга, медицинской помощи и др.), отсутствие возможностей свободного выбора досуговых услуг.

Формирование и развитие социальной инфраструктуры в регионе, по нашему 
мнению, предполагает создание и расширение как объектов, обеспечивающих необходимый уровень жизни (школы, поликлиники, спортивные комплексы), так и объектов социальной инфраструктуры комфорта (для свободного выбора досуга парковые зоны, снаряды для занятия физической культурой и др.), а также объектов культурного наследия, исторических памятников, туристических маршрутов.

В настоящее время источниками инвестиций для социально-экономического развития региона, повышение качества жизни в регионе являются средства федерального бюджета и средства регионального бюджета. Инвестирование в условиях кризиса в развитие региональной инфраструктуры (технической и социальной) в

\section{СПИСОК ЛИТЕРАТУРЫ}

1. Шлемина, И.В. Основные проблемы функционирования социокультурной среды // Проблемы современного антропосоциального познания; под ред. Н.В. Попкова. - Брянск, БГТУ, 2014. - С. 97-101.

2. Шлемина, И.В. Сущность социокультурной среды и основные проблемы ее функционирования // Проблемы современного антропосоциального познания; под ред. Н.В. Попкова. - Брянск, БГТУ, 2012. - С. $79-84$.

\section{Сведения об авторах:}

\section{Шлемина Ирина Владимировна}

канд. экон. наук, доцент

кафедры «Экономика, организация

производства, управление»

Брянского государственного

технического университета,

E-mail: Lady-x7@yandex.ru новых жилых комплексах остается неопределенным по срокам и источникам инвестиций.

\section{Заключение}

Теоретический и эмпирический анализ развития социальной инфраструктуры в регионе в условиях экономического кризиса позволил выявить следующие тенденции:

1) снижение покупательной способности, экономия на качестве инфраструктурных объектов в проектах жилой недвижимости;

2) потребность для сохранения высокого уровня качества жизни в создании необходимой инфраструктуры и инфраструктуры комфорта и развития.

1. Shlemina, I.V. Main problems of the sociocultural environment functioning // Problems of modern anthroposocial knowledge; under the editorship of N.V. Popkov. - Bryansk, BSTU, 2014. - P. 97-101.

2. Shlemina, I.V. Essence of the sociocultural environment and main problems of its functioning // Problems of modern anthroposocial knowledge; under the editorship of N.V. Popkov. - Bryansk, BSTU, 2012. - P. 79-84.

Статья поступила в редколлегию 26.07.2016. Реиензент: д-р экон. наук, наук., профессор зав кафедрой "Таможенное дело и маркетинг"

Брянского государственного университета им. академика И.Г. Петровского Глушак Николай Владимирович 